\title{
Reproduction Control in Coptodon zillii using Abrus precatorius Root Bark Diets as Fertility Inhibitor Agent
}

\author{
B. J. Akin-Obasola ${ }^{1 *}$ \\ ${ }^{1}$ Department of Fisheries and Aquaculture Management, Ekiti State University, Ado-Ekiti, Ekiti State, \\ Nigeria.
}

Author's contribution

The sole author designed, analyzed, interpreted and prepared the manuscript.

Article Information

DOI: $10.9734 / A R R B / 2021 / v 36 i 530381$

Editor(s):

(1) Dr. Bechan Sharma, University of Allahabad, India.

Reviewers:

(1) Cristiano C. Coutinho, Universidade Federal do Rio de Janeiro, Brazil. (2) Cacilda Thais Janson Mercante, Instituto de Pesca Secretaria da Agricultura do Governo do estado de São Pau ,Brazil. Complete Peer review History: http://www.sdiarticle4.com/review-history/68159

Original Research Article

Received 10 March 2021

Accepted 14 May 2021

Published 12 June 2021

\begin{abstract}
The antifertility effects of Abrus precatorius root bark meal (APRB) on Coptodon zillii juvenile was determined by a 42 days feeding experiment, with the inclusion levels of $0 \mathrm{~g}, 6 \mathrm{~g}, 12 \mathrm{~g}, 18 \mathrm{~g}$ and $24 \mathrm{~g} / \mathrm{kg}$ diet. Water volume of 20 litres in a plastic tank $(50 \mathrm{~cm} \times 27 \mathrm{~cm} \times 35 \mathrm{~cm}$ dimension) was maintained throughout the period of experiment. Coptodon zillii was fed at $4 \%$ body weight. In male fish, testis weight, milt volume, milt count and motility duration reduced with increase in inclusion level and there were significant differences $(P<0.05)$ in the treatments used. Histology of testis at $0 \mathrm{~g}$ of APRB $/ \mathrm{kg}$ diet showed primary and secondary spermatocytes in the seminiferous tubule, connective tissue was clearly seen. In treatments $6 \mathrm{~g}, 12 \mathrm{~g}, 18 \mathrm{~g}$ and $24 \mathrm{~g} \mathrm{APRB} / \mathrm{kg}$ diets, there were increase in interstitial cell, eroded connective tissue and necrosis. In female fish, ovary weight, fecundity, relative fecundity and gonadosomatic index reduced with increase in the concentration of treatments used. Histology of the ovary at $0 \mathrm{~g} \mathrm{APRB} / \mathrm{kg}$ diet showed developing oocytes while treatments $6 \mathrm{~g}, 12 \mathrm{~g}, 18 \mathrm{~g}$ and $24 \mathrm{~g}$ revealed reduced oocytes, increase in interstitial cell, alteration in ovary development and necrosis. The research revealed that Abrus precatorius root bark meal may be effective in controlling reproduction in Coptodon zillii.
\end{abstract}

*Corresponding author: E-mail: bola.akinobasola@eksu.edu.ng; 
Keywords: Coptodon zillii; Abrus precatorius; root bark diets; fertility agent.

\section{INTRODUCTION}

Tilapia possesses an impressive range of qualities that made it more suitable for aquaculture in the $21^{\text {st }}$ century which include their abilities to readily reproduce in captivity, grow quickly to consumable size (in about six months), tolerate a wide range of environmental conditions, resistance to stress and disease, feeding on low trophic level, with versatile food habitats, acceptance of artificial feed immediately after york-sac absorption, adapt to a variety of culture systems and are considered palatable marketable and nutritious [1].

Regardless of the widely reported tilapia aquaculture global production and progress over the years, there are several challenges commonly associated with their reproductive ability that inhibit their full aquaculture potential. These include precocious maturity and frequent breeding behaviour [2] leading to increased competition for supplemented food, stunted somatic growth, crowding and stunting, competition between fries and fingerlings for food, space and dissolved oxygen [3]. This has resulted in the development of various techniques to control unwanted tilapia reproduction which include: Periodic harvesting of fry and fingerlings, Monosex culture, culture in cages, high density culture, biological control, Sterilization and eradication using organic toxicants and/or other chemicals. However, all the techniques have their limitations which include; intensive labour, brood stock contamination, expertize in brood stock selection, consumer acceptance of hormonally sex reversed fish (even in countries where hormonal applications to food fish are accepted practice [3]. The use of medicinal plants which is readily available, easy to apply, no requirement for highly trained labour, less expensive and its effect is reversible in controlling tilapia population has been able to overcome these problems [4].

Abrus precatorius with the common name rosary pea belong to the family Fabaceae.

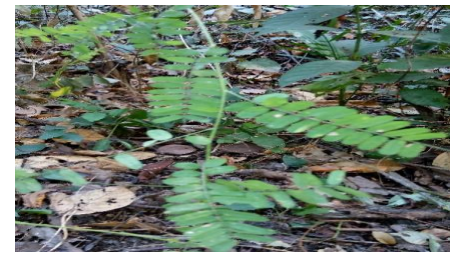

Plate 1. Abrus precatorius plant
It is a slender twiner with alternately placed compound leaves. Each leaf has about 20 pairs of narrow, oblong leaflets, looking like a delicate feather. The plant is native to the tropics. It grows by the seashore among the undergrowth and in hedges. It possess contraceptive agents such as saponin, alkaline, tannin, abraline, abrusgenicacid-methyl-ester, abruslactone, abrussic-acid, that makes it a perfect specimen for controlling the prolificacy in Coptodon zillii [5].

Work has been done on the effects of Abrus precatorius on other animals. Johan et al. [6]. Worked on the antifertility effects of ethanolic seed extract of Abrus precatorius L. on sperm production and DNA integrity in adult male mice. Okoko et al. [7] studied the anti-ovulatory and anti-implantation potential of the methanolic extract of seeds of Abrus precatorius in the rat. Sinha [8] examined the post-testicular antifertility effects of Abrus precatorius seed extract in albino rats and Nuha et al. [9] analysed the antifertility effects of Abrus Precatorius Etahanol seeds extract on female rats. Bernstein et al. [10] worked on the safety of consuming traditional medicinal plants during pregnancy while Tabasum et al. [11] examined the subchronic toxicity of orally administered methanol $(70 \%)$ seed extract of Abrus precatorius L. in Wistar Albino rats.

The present study evaluated the effect of feeding Abrus precatorius on Coptodon Zillii male and female reproductive organ, assessed the utilization and growth of $C$. zillii post juvenile fed Abrus precatorius root bark meal and analyzed the effects on the histopathology of the gonad.

\section{MATERIALS AND METHODS}

The experiment was carried out at the teaching and research farm, Ekiti State University using ten 30litres glass tanks having a dimension of $70 \mathrm{~cm} \times 45 \mathrm{~cm} \times 40 \mathrm{~cm}$. Well water of 20 litres was maintained in all the plastic tanks throughout the period of the experiment. Fingerlings of Coptodon zillii post juvenile (150) were purchased from a reliable source and acclimatized for 3days. The fish was randomly stocked at the rate of ten fish per tank. Each treatment was replicated thrice and the experiment lasted for 42 days. The diet used was prepared using; fish meal (menhaden), soya bean meal, yellow maize, vegetable oil, cod liver oil, vitamin, mineral premix and starch. 
Control treatments and treatments $1,2,3,4$ were prepared adding $0 \mathrm{~g}, 6 \mathrm{~g}, 12 \mathrm{~g}, 18 \mathrm{~g}$ and $24 \mathrm{~g}$ of milled Abrus precatorius root / $\mathrm{kg}$ diets respectively to provide $40 \%$ crude protein level required by tilapia. The diets were pelletized using $2 \mathrm{~mm}$ die sun dried and packed into well labeled containers and stored in a cool and dry place. Fish were fed at $4 \%$ body weight twice a day at 09:00 - 09:30 hours and 17:00 - 17:30 hours and were weighed weekly. On the termination of the experiment, the final weight of each fish was taken. Feeding rate was adjusted fortnightly according to increase in body weight. Uneaten feed and faeces were siphoned out every morning. Temperature, dissolved oxygen and $\mathrm{pH}$ were analyzed on the first day and last day before water was changed fortnightly. Using Mair et. al. [2] methods, fragments of ovaries and testis were collected and fixed in formalin for 24 hours, embedded in paraffin, sectioned at $5 \mu \mathrm{m}$ using microtome and stained with haematoxylin eosin for histological analysis. Photomicrographs were taken with Leitz (Ortholux) microscope with camera. Milt production and quality were determined at the end of the experiment. Concentration of sperm was determined by counting the number of spermatozoa in sample diluted with distilled water in a Burker haemocytometer under 400x magnification. Histological interpretation was done using [12] method.

\section{RESULTS}

\subsection{Male Coptodon zilli Fed Abrus precatorious Root Bark Meal}

From Table 2, there were no significant differences $(P<0.05)$ in the testis weight while there were significant differences in fish initial weight, fish final weight, milt volume, milt count and motility duration.

\subsection{Female C. zilli fed Abrus precatorious Root Bark Diets}

As shown in Table 3, there were no variation in the egg size. The ovary weight showed no significant differences between treatments $6 \mathrm{~g}$ and $12 \mathrm{~g}$ but treatments $0 \mathrm{~g}, 18 \mathrm{~g}$ and $24 \mathrm{~g}$ differed. Size of egg were similar in treatments $12 \mathrm{~g}, 18 \mathrm{~g}$ and $24 \mathrm{~g}$. Control treatment had the highest fecundity and differed in all the threatments.

Table 1. Composition of experimental diet using Abrus precatorius root bark diets

\begin{tabular}{llllll}
\hline Ingredients & $\begin{array}{l}\text { Control } \\
\text { (g/kg) }\end{array}$ & $\mathbf{T}_{\mathbf{1}} \mathbf{( g / \mathbf { k g } )}$ & $\mathbf{T}_{\mathbf{2}} \mathbf{( g / \mathbf { k g } )}$ & $\mathbf{T}_{\mathbf{3}} \mathbf{( g / \mathbf { k g } )}$ & $\mathbf{T}_{\mathbf{4}} \mathbf{( g / \mathbf { k g } )}$ \\
\hline Fish meal (27.5\%) & 275 & 275 & 275 & 275 & 275 \\
Soya meal (38\%) & 380 & 380 & 380 & 380 & 380 \\
Yellow maize (24\%) & 240 & 240 & 240 & 240 & 240 \\
Cod-liver oil & 30 & 30 & 30 & 30 & 30 \\
Veg oil & 20 & 20 & 20 & 20 & 20 \\
Vit - mineral premix & 30 & 30 & 30 & 30 & 30 \\
Starch & 25 & 25 & 25 & 25 & 25 \\
Abrus precatorious & 0 & 6 & 12 & 18 & 24 \\
\hline Total & 1000 & 1000 & 1000 & 1000 & 1000 \\
\hline
\end{tabular}

Table 2. Reproductive parameters of male C. zilli fed Abrus precatorious root bark diets

\begin{tabular}{llllll}
\hline \multicolumn{5}{c}{ Treatments } \\
\hline Parameters & $\mathbf{0 g}$ & $\mathbf{6 g}$ & $\mathbf{1 2 g}$ & $\mathbf{1 8 g}$ & $\mathbf{2 4 g}$ \\
\hline $\begin{array}{l}\text { Fish initial } \\
\text { weight }\end{array}$ & $10.30 \pm 20^{\mathrm{c}}$ & $7.20 \pm 0.01^{\mathrm{b}}$ & $10.30 \pm 0.10^{\mathrm{c}}$ & $10.15 \pm 0.05^{\mathrm{c}}$ & $6.30 \pm 0.01^{\mathrm{a}}$ \\
Fish final & $19.15 \pm 0.25^{\mathrm{c}}$ & $13.35 \pm 20^{\mathrm{a}}$ & $17.70 \pm 20^{\mathrm{b}}$ & $17.55 \pm 0.15^{\mathrm{b}}$ & $13.65 \pm 0.05^{\mathrm{a}}$ \\
weight & & & & & \\
Milt volume & $0.50 \pm 0.10^{\mathrm{b}}$ & $0.46 \pm 0.07^{\mathrm{ab}}$ & $0.45 \pm 0.07^{\mathrm{ab}}$ & $0.35 \pm 0.02^{\mathrm{ab}}$ & $0.21 \pm 0.01^{\mathrm{a}}$ \\
Milt count & $3.09 \pm 0.50^{\mathrm{c}}$ & $2.02 \pm 0.10^{\mathrm{b}}$ & $1.78 \pm 0.11^{\mathrm{b}}$ & $1.15 \pm 0.30^{\mathrm{ab}}$ & $0.63 \pm 0.236^{\mathrm{a}}$ \\
Testes weight & $0.53 \pm 0.00^{\mathrm{a}}$ & $0.52 \pm 0.00^{\mathrm{a}}$ & $0.53 \pm 0.00^{\mathrm{a}}$ & $0.52 \pm 0.00^{\mathrm{a}}$ & $0.52 \pm 0.00^{\mathrm{a}}$ \\
Motility & $4.14 \pm 0.14^{\mathrm{e}}$ & $3.09 \pm 0.00^{\mathrm{d}}$ & $2.51 \pm 0.04^{\mathrm{c}}$ & $0.52 \pm 0.02^{\mathrm{b}}$ & $0.16 \pm 0.01^{\mathrm{a}}$ \\
\hline
\end{tabular}


Table 3. Reproductive parameters of female C. zilli fed Abrus precatorious root bark diets

\begin{tabular}{llllll}
\hline \multicolumn{5}{c}{ Treatments } \\
\hline Parameters & $\mathbf{0 g}$ & $\mathbf{6 g}$ & $\mathbf{1 2 g}$ & $\mathbf{1 8 g}$ & $\mathbf{2 4 g}$ \\
\hline Fish final weight & $10.30 \pm 0.20^{\mathrm{c}}$ & $7.20 \pm 0.01^{\mathrm{b}}$ & $10.30 \pm 0.10^{\mathrm{c}}$ & $10.15 \pm 0.05^{\mathrm{c}}$ & $6.3 \pm 0.01^{\mathrm{a}}$ \\
Fish initial weight & $19.15 \pm 0.25^{\mathrm{c}}$ & $13.35 \pm 0.15^{\mathrm{a}}$ & $17.70 \pm 0.10^{\mathrm{b}}$ & $17.55 \pm 0.15^{\mathrm{b}}$ & $13.65 \pm 0.05^{\mathrm{a}}$ \\
Ovary weight & $1.52 \pm 0.01^{\mathrm{d}}$ & $1.15 \pm 0.01^{\mathrm{c}}$ & $1.17 \pm 0.01^{\mathrm{c}}$ & $1.09 \pm 0.00^{\mathrm{b}}$ & $0.94 \pm 0.00^{\mathrm{a}}$ \\
Egg mean wet weight & $0.01 \pm 0.00^{\mathrm{a}}$ & $0.01 \pm 0.00^{\mathrm{b}}$ & $0.01 \pm 0.00^{\mathrm{b}}$ & $0.01 \pm 0.00^{\mathrm{c}}$ & $0.01 \pm 0.00^{\mathrm{c}}$ \\
Size of egg & $0.91 \pm 0.00^{\mathrm{c}}$ & $0.92 \pm 0.00^{\mathrm{c}}$ & $0.85 \pm 0.01^{\mathrm{a}}$ & $0.85 \pm 0.00^{\mathrm{a}}$ & $0.81 \pm 0.00^{\mathrm{a}}$ \\
Fecundity & $142.3 \pm 40.00^{\mathrm{d}}$ & $89.50 \pm 0.00^{\mathrm{c}}$ & $88.17 \pm 0.00^{\mathrm{c}}$ & $68.01 \pm 0.01^{\mathrm{b}}$ & $56.06 \pm 0.06^{\mathrm{a}}$ \\
Relative fecundity & $1.94 \pm 0.00^{\mathrm{e}}$ & $1.18 \pm 0.00^{\mathrm{d}}$ & $1.12 \pm \pm 0.01^{\mathrm{c}}$ & $0.88 \pm 0.01^{\mathrm{b}}$ & $0.76 \pm 0.01^{\mathrm{a}}$ \\
Gonadosomatic index & $2.25 \pm 0.16^{\mathrm{c}}$ & $1.54 \pm 0.00^{\mathrm{b}}$ & $1.46 \pm 0.00^{\mathrm{ab}}$ & $1.35 \pm 0.02^{\mathrm{ab}}$ & $1.26 \pm 0.02^{\mathrm{a}}$ \\
\hline
\end{tabular}

\subsection{Growth Parameters and Nutrient Utilization}

As shown in Table 4, weight gain was high in the control experiment but lowest in fish fed $6 \mathrm{~g} / \mathrm{kg}$ APRB diet. There were no significant difference in feed conversion ratio between treatment 0 and $6 ; 12$ and 18 . Weight gained and growth rate were similar in treatments $12 \mathrm{~g}, 18 \mathrm{~g}$ and $24 \mathrm{~g}$ but differed in treatments $0 \mathrm{~g}$ and $6 \mathrm{~g}$. Feed conversion ratio was least in treatment $24 \mathrm{~g}$ and was significantly different from other treatments.

\subsection{Physico-chemical Parameters}

Table 5 showed there were no significant differences in the $\mathrm{pH}$ of the water used in treatments $0 \mathrm{~g}, 6 \mathrm{~g}$, and $12 \mathrm{~g}$. Temperature were not significantly different in treatments $0,6,18$ and 24 while dissolved oxygen were not similar in all the treatments used.

\subsection{Histological Analysis}

Fig. 1a, the section of testis in Coptodon zillii fed Og APRB/kg diet showed primary (PS) and secondary spermatocytes (SS) in the seminiferous tubule, connective tissue (CT) is clearly seen while Fig. $1 \mathrm{~b}$ is the section of testis in C.zillii fed $6 \mathrm{~g} \mathrm{APRB} / \mathrm{kg}$ diet showing eroded connective tissue (ECT) and increase in interstitial cell (IIC). Fig. 1C is showing the section of testis in C.zillii fed $12 \mathrm{~g} \mathrm{APRB} / \mathrm{kg}$ diet which revealed eroded connective tissue (ECT) and increase in interstitial cell (IIC). C.zillii fed $18 \mathrm{~g}$ APRB/kg diet Fig. (1d) showed eroded connective tissue (ECT), increase in interstitial cell (IIC) and necrosis while Fig. 1e; section of testis in C.zillii fed $24 \mathrm{~g} \mathrm{APRB} / \mathrm{kg}$ diet showed severely eroded connective tissue (ECT) alteration in testicular architecture and severe increase in interstitial cell (IIC).

Table 4. Growth parameters and nutrient utilization of Coptodon zillii fed Abrus pecatorious back diets

\begin{tabular}{llllll}
\hline \multicolumn{5}{c}{ Treatments } \\
\hline Parameters & $0 \mathrm{~g}$ & $6 \mathrm{~g}$ & $12 \mathrm{~g}$ & $18 \mathrm{~g}$ & $24 \mathrm{~g}$ \\
\hline Initial weight of fish & $10.30 \pm 0.20^{\mathrm{c}}$ & $7.20 \pm 0.01^{\mathrm{b}}$ & $10.30 \pm 0.10^{\mathrm{c}}$ & $10.15 \pm 0.05^{\mathrm{c}}$ & $6.3 \pm 0.01^{\mathrm{a}}$ \\
Final weight of fish & $19.15 \pm 0.25^{\mathrm{c}}$ & $13.35 \pm 0.15^{\mathrm{a}}$ & $17.70 \pm 0.10^{\mathrm{b}}$ & $17.55 \pm 0.15^{\mathrm{b}}$ & $13.65 \pm 0.05^{\mathrm{a}}$ \\
Feed fed & $17.2 \pm 0.41^{\mathrm{c}}$ & $12.1 \pm 0.20^{\mathrm{b}}$ & $17.39 \pm 0.25^{\mathrm{c}}$ & $17.01 \pm 0.21^{\mathrm{c}}$ & $10.56 \pm 0.14^{\mathrm{a}}$ \\
Weight gain & $8.89 \pm 0.01^{\mathrm{c}}$ & $6.15 \pm 0.05^{\mathrm{a}}$ & $7.40 \pm 0.00^{\mathrm{b}}$ & $7.40 \pm 0.10^{\mathrm{b}}$ & $7.35 \pm 0.05^{\mathrm{b}}$ \\
Growth rate & $0.21 \pm 0.00^{\mathrm{c}}$ & $0.14 \pm 0.00^{\mathrm{a}}$ & $0.17 \pm 0.00^{\mathrm{b}}$ & $0.17 \pm 0.00^{\mathrm{b}}$ & $0.17 \pm 0.00^{\mathrm{b}}$ \\
Feed conversion ratio & $1.94 \pm 0.03^{\mathrm{b}}$ & $1.96 \pm 0.01^{\mathrm{b}}$ & $2.35 \pm 0.05^{\mathrm{c}}$ & $2.29 \pm 0.00^{\mathrm{c}}$ & $1.44 \pm 0.03^{\mathrm{a}}$ \\
\hline
\end{tabular}

Table 5. Physico-chemical parameters of water

\begin{tabular}{llllll}
\hline \multicolumn{5}{c}{ Treatments } \\
\hline Parameters & $\mathbf{0}$ & $\mathbf{6}$ & $\mathbf{1 2}$ & $\mathbf{1 8}$ & $\mathbf{2 4}$ \\
\hline $\mathbf{p H}$ & $6.62 \pm 0.02^{\mathrm{a}}$ & $6.47 \pm 0.02^{\mathrm{a}}$ & $6.60 \pm 0.00^{\mathrm{a}}$ & $6.05 \pm 0.05^{\mathrm{b}}$ & $5.8 \pm 0.02^{\mathrm{c}}$ \\
Temperature & $22.50 \pm 0.50^{\mathrm{a}}$ & $23.50 \pm 0.50^{\mathrm{a}}$ & $24.70 \pm 0.30^{\mathrm{b}}$ & $23.5 \pm 0.05^{\mathrm{a}}$ & $23.00 \pm 0.00^{\mathrm{a}}$ \\
Dissolved oxygen & $5.45 \pm 0.05^{\mathrm{a}}$ & $5.32 \pm 0.02^{\mathrm{b}}$ & $5.22 \pm 0.02^{\mathrm{c}}$ & $5.13 \pm 0.03^{\mathrm{d}}$ & $4.95 \pm 0.05^{\mathrm{e}}$ \\
\hline
\end{tabular}




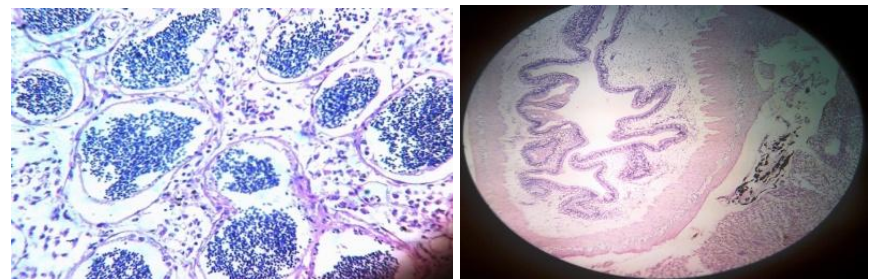

a. C. zillii fed $0 \mathrm{~g}$ b. C. zillii fed $6 \mathrm{~g}$

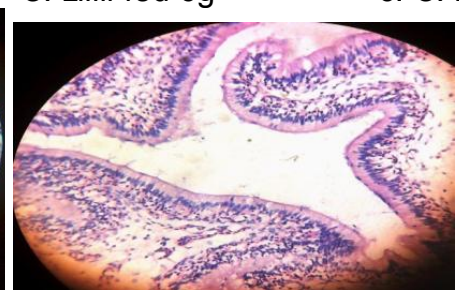

e. C. zillii fed $24 \mathrm{~g}$

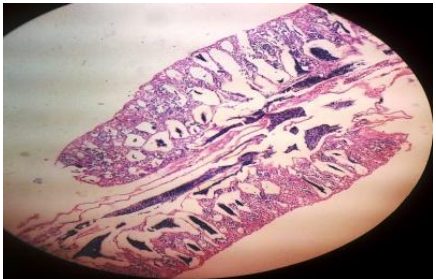

c. C. zillii fed $12 \mathrm{~g}$

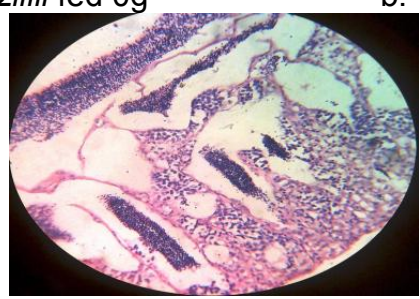

d. C. zillii fed $18 \mathrm{~g}$

Fig. 1(a-e). Sections of testis in C. zillii fed APRB/kg diets. Magx100

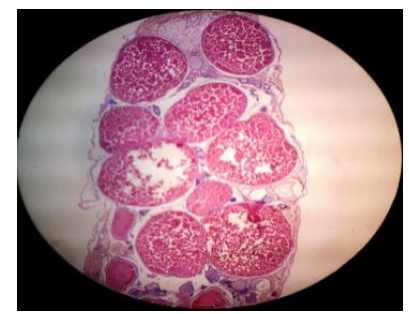

a. C. zillii fed $0 \mathrm{~g}$

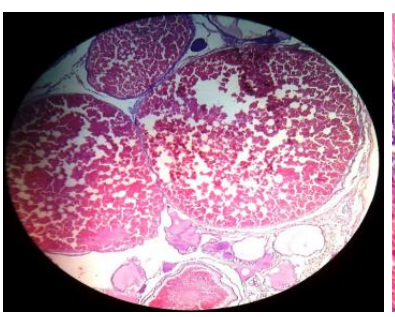

b. C. zillii fed $6 \mathrm{~g}$

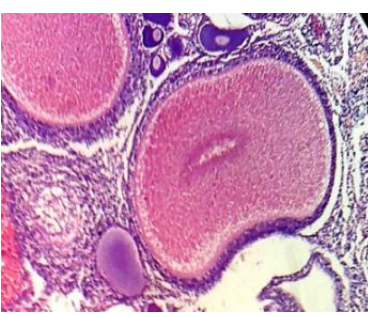

c. C. zillii fed $12 \mathrm{~g}$

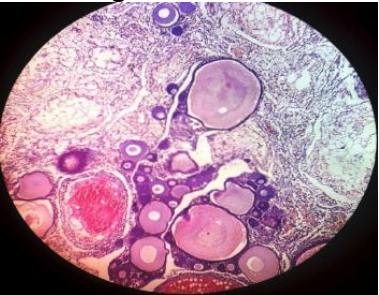

d. C. zillii fed $18 \mathrm{~g}$

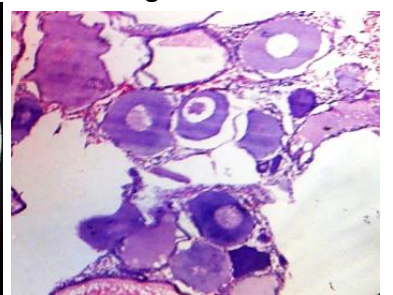

e. C. zillii fed $24 \mathrm{~g}$

Fig. 2(a-e). Sections of ovary in C. zillii fed APRB/kg diets. Magx100

Fig. 2a shows the section of ovary in C. zillii fed $0 \mathrm{~g}$ of $\mathrm{APRB} / \mathrm{kg}$ diet which revealed developing oocytes (DO) that were surrounded by a thin wall. Fig. $2 \mathrm{~b}$, the section of ovary in C. zillii fed $6 \mathrm{~g}$ of $\mathrm{APRB} / \mathrm{kg}$ diet showed reduced oocytes (RO) in the ovary. Fig. 2c, the section of ovary in C. zillii fed $12 \mathrm{~g}$ of APRB/kg diet showed necrosis (NE) in the ovary while Fig. $2 \mathrm{~d}$ showed $C$. zillii fed $18 \mathrm{~g}$ of APRB/kg diet showed necrosis (NE). Fig. 2e, the section of ovary in C. zillii fed $24 \mathrm{~g}$ of APRB/kg diet showed increase in interstitial cell (IIC), alteration in ovary development (AOD) and necrosis. Fig. 2d, the section of ovary in C. zillii fed $18 \mathrm{~g}$ of $A P R B / k g$ diet showed alteration in ovary development (AOD) and necrosiss (NE).

\section{DISCUSSION}

\subsection{Histology of Testis of C. zillii fed APRB (Abrus Precatorious root bark) Diets}

Histological section of C.zillii fed Og APRB showed primary and secondary spermatozoa in the seminiferous tubule and the connective tissue was clearly seen. This agrees with AkinObasola and Jegede [13] report where Gossypium Herbaceum root back meal was used as fertility inhibitor and histological analysis revealed sparmatozoa were released into the lumen of seminiferous tubule in the control experiment. In the fish fed $6 \mathrm{~g}, 12 \mathrm{~g}, 18 \mathrm{~g}$, 
APRB/kg diet, the section of testis of C.zillii showed eroded connective tissue and increase in insterstatial cell. Similar disruption in the testis of C.zillii fed neem was also reported by Jegede [14] such that an alteration occurred in the testicular architecture and lystic seminiferous tubules, sever tissue atrophy, spermatids disintegration and necrosis were seen.

\subsection{Histology of Ovary in C. zillii fed APRB Diet}

Histological section of $C$. zillii fed $0 \mathrm{~g} \mathrm{APRB/kg}$ showed developing oocytes surrounded by a thin wall, no pathological lesions were observed, atretic follicles were less visible and normal olive green colour of ovaries was maintained in $C$. zillii fed $6 \mathrm{~g} \mathrm{APRB} / \mathrm{kg}$ diet, the section showed reduced oocytes in the ovary. C. zillii fed $24 \mathrm{~g}$ of $\mathrm{APRB} / \mathrm{kg}$ diet, showed increase in interstitial cell alteration in ovary development and necrosis; this report agrees with Asuqou et al. [15] who worked on the effect of ethanolic leaf extract of Spondias mombin on the pituitary-gonadal axis of female Wistar rats which revealed damaged ovarian tissues.

In the fish fed APRB diets, there were changes in colour of ovaries from olive green to off white colouration, increased atretic follicles, ruptured follicle, as well as increase in interstitial cell and alteration in ovary development, these disagrees with Akin-Obasola and Jegede, [16] where the histological analysis of female redbelly Tilapia, Tilapia zillii (Gervais, 1848) ovary fed bitter melon, Momordica charantia (Cucurbitaceae) revealed a colour that was not altered.

\subsection{Reproductive Performance in C. zilli Fed APRB Root Bark Meal}

\subsubsection{Male C. zillii}

Milt volume was higher in control diet and decreases with increasing concentration of APRB diet $(P \leq 0.05)$. Milt count, as well as motility also decreases with increase in inclusion level of APRB diet, Akin-Obasola and Jegede (2014) gave similar report on the decrease in milt motility and milt count when $C$. zillii was fed 20 , 40,60 and $80 \mathrm{~g} / \mathrm{kg}$ diet of Momordica charantia diet for 80 days. There were no siginificant differences in the milt volume in all the treatment used. This was also reported by Akin-Obasola and Jegede [16] when C.zillii was fed bitter melon leaf diets.

\subsubsection{Female C. zillii}

Egg size and fecundity decreases with increase in the inclusion level of APRB/kg diet. Also, there were significant differences in fish fecundity. The egg size as well as fecundity decreases with increase in the inclusion levels. These results corroborates Sonia et.al. [17], who studied the anti-fertility effect of bitter lemon on female mice.

\subsection{Growth Performance and Nutrient Utilization of C. zillii fed Abrus Precatorious Root Back Meal (APRB) Diets}

The optimal and best growth response was observed in the control experiment which was fed basal diet. Feed conversion ratio was better in the control experiment, Feed conversion ratio was between 1.4 - 2.4; which can be considered a good result as recommended by Ofori et al. [18] who recommended $1.5-2.0$.

Nuha [9] examined the reversion of the histological alteration and removal of any residual accumulates of Abrus precatorius and reported this could be achieved within 2 weeks after any feeding experiment.

\section{CONCLUSION}

The result of this study showed that Abrus precatorious can control Coptodon zillii population acting as a perfect anti-fertility agent. Treatment $6 \mathrm{~g} \mathrm{APRB} / \mathrm{kg}$ is recommended for use by farmers as the feed conversion ratio and the histological analysis were similar to the control treatment. Though, fish fed $24 \mathrm{~g} \mathrm{APRB} / \mathrm{kg}$ had the list feed conversion ratio, it is not recommended as the concentration used at this level greatly altered the organs of the fish fed.

Reversion of the histological alteration and removal of any residual accumulates could be achieved within 2 weeks as reported in former documented researches.

\section{COMPETING INTERESTS}

Author has declared that no competing interests exist.

\section{REFERENCES}

1. Arrignon JCV. Tilapia. The tropical Agriculturalist. Centre for Tropical Vertinary 
Medicine, University of Edinburgh. In: Anthony, J. S. and Rene, C. (eds). 1998;78.

2. Mair GC. Tilapia genetics and breeding in Asia. In: R. D. Guerrero III and M. R. Guerrerodel Castillo (eds.). Tilapia Farming in the $21^{\text {st }}$ Century, Proceedings of the International; 2002.

3. Fortes RD. Review of techniques and practices in controlling tilapia populations and identification of methods that may have practical applications in nauru including a national tilapia plan. Aquaculture Technical Paper / Secretariat of the Pacific Community. Published by Secretariat of the pacific Community. Noumea, New Caledonia. 2005;11-24.

4. Priya G, Saravanan K, Renuka C. Medicinal plants with potential antifertility activity- A review of sixteen years of herbal medicine research (1994-2010). Inter. Journal. of PharmTech Research, USA. 2012;4(1):481-494.

5. Narendra G, Atul B. Ethno botanical and phytopharmacological potentials of Abrus precatorious L. Asian Pacific Journal of Tropical Biomedicine. 2014;27-34.

6. Jahan S, Rasool S, khan MA, Ahmad M, Zafar M, Arsahd M, Abbasi AM. Antifertility effects of ethanolic seed extract of Abrus precatorius $\mathrm{L}$. on sperm production and DNA integrity in adult male mice, Journal of Medicine Plant. Res. 2009;3(10):809814.

7. Okoko II, Osinubi AA, Olabiyi OO, Kusemiju TO, Noronha CC, Okanlawon AO. Antiovulatory and anti-implantation potential of the methanolic extract of seeds of Abrus precatorius in the rat. Endocr. Pract. 2010;16(4):554-60.

8. Sinha R. Post-testicular antifertility effects of Abrus precatorius seed extract in albino rats. Journal of Ethnopharmacol. 1990;28(2):173-81.

9. Nuha ME. Agabna Sania Abdalla Ibrahim Shaddad Antifertility Effects of Abrus Precatorius Etahanol Seeds Extract on Female Rats. World Journal of Pharmaceutical Research. 2016;5(5):281293.
10. Bernstein N, Akram M, Yaniv-Bachrach Z, Daniyal $M$. Is it safe to consume traditional medicinal plants during pregnancy? Phytother Res. 2021;35(4):1908-1924.

11. Tabasum S, Khare S, Jain K. Subchronic toxicity assessment of orally administered methanol (70\%) Seed Extract of Abrus precatorius L. in Wistar Albino Rats. Turkey Journal of Pharm Science. 2019;16(1):88-95.

12. Fitzsimmons K. Tilapia culture. In; Kelly A.M. and Silverstein. Aquaculture in the $21^{\text {st }}$ Century. american fisheries society, Symposium 46, Bethesda, Maryland, USA. 2005;563-590.

13. Akin-Obasola BJ, Jegede T. Control of female Oreochromis niloticus (Nile tilapia) reproduction using Gossypium herbaceum (cotton) root bark meal as fertility inhibitor. Proceedings of the $31^{\text {st }}$ Annual Conference of Fisheries Society of Nigeria. 2016:142144.

14. Jegede T, Oyedapo F. Histology of gonads in Tilapia zillii (gervais 1848) fed neem (Azadirachta indica) leaf meal diets. $8^{\text {th }}$ International Symposium on Tilapia in Aqua. 2008;1129-1134.

15. Asuquo OR, Oko OOK, Brownson ES, Umoetuk GB. Effects of ethanolic leaf extract of spondias mombin on the pituitary-gonadal axis of female wistar rats. Elsevier. Asian Pacific Journal of Reproduction. 2013;2(3):169-173.

16. Akin-Obasola BJ, Jegede T. Histological analysis of female redbelly Tilapia, Tilapia zillii (Gervais, 1848) ovary, fed bitter melon, Momordica charantia (Cucurbitaceae) leaf meal. Journal of Agricultural Science (JAS). 2014b:6(11):229-237.

17. Sonia S, Shruti T, Bhupesh S, Komal S. Momordica charantia linn: $A$ comprehensive review on bitter remedy. Journal of Pharmaceutical Research and Opinion. 2011;1 (2): 41-47.

18. Ofori JK, Dankwa HR, Brummett R, Abban EK. Producing Tilapia in Small Cage in West Africa. World fish Center Technical Manual. No 1952. The World fish Center, Penang, Malaysia. 2009;16.

(c) 2021 Akin-Obasola; This is an Open Access article distributed under the terms of the Creative Commons Attribution License (http://creativecommons.org/licenses/by/4.0), which permits unrestricted use, distribution, and reproduction in any medium, provided the original work is properly cited.

Peer-review history:

The peer review history for this paper can be accessed here: http://www.sdiarticle4.com/review-history/68159 